\title{
Haroldo de campos e Herberto Helder: a antropofagia como criação poética
}

Haroldo de Campos and Herberto Helder : the antropophagy as poetic creation

\author{
Geovanna Marcela da Silva GUIMARÃES ${ }^{1}$ \\ Universidade Federal do Pará (UFPA) \\ Izabela Guimarães Guerra LEAL ${ }^{2}$ \\ Universidade Federal do Pará (UFPA)
}

RESUMO: O objetivo deste artigo é discutir o sentido que o conceito de Antropofagia, desenvolvido por Oswald de Andrade em 1928, possui nas obras poéticas de Haroldo de Campos (1939-2003) e de Herberto Helder (1930-). Para isso, a antropofagia será concebida, em termos poéticos, como uma forma de apropriação violenta da tradição, no sentido de que ela irá encenar uma desconstrução do cânone universal. Haroldo de Campos e Herberto Helder propõem uma releitura crítica e criativa da tradição, sendo que o ponto principal de análise é a demonstração de como a antropofagia pode ser entendida como instrumento de criação poética.

PALAVRAS-CHAVE: Haroldo de Campos. Herberto Helder. Antropofagia.Tradição. Poesia.

ABSTRACT: The objective of this article is to discuss which sense the concept of antropophagy, developed by Oswald de Andrade in 1928, bears at the poetics works of Haroldo de Campos (1939 2003) and Herberto Helder (1930-). For that, the antropophagy will be designed, in poetic terms, as a violent appropriation of tradition in the sense that it will stage a deconstruction of universal canon. Haroldo de Campos and Herberto Helder propose a critical and creative re-reading of tradition, being the main point of analysis the demonstration of how antropophagy can be understood as an instrument of poetic creation.

KEY-WORDS: Haroldo de Campos. Herberto Helder. Antropophagy. Tradition. Poetry.

\section{Introdução}

O principal objetivo deste trabalho é propor um diálogo entre dois poetas contemporâneos, cujos trabalhos são marcados pela criação e inovação. Haroldo de Campos e Herberto Helder possuem papéis importantes no panorama da poesia contemporânea, pois dedicaram parte do seu trabalho criativo à constante renovação da poesia, ressaltando que a linguagem poética vai muito além do senso comum e que a poesia não é simplesmente a descrição de paisagens e sentimentos, mas é também uma reflexão sobre a própria escrita. É

${ }^{1}$ Licenciada em Letras (Habilitação em Língua Portuguesa) pela Universidade Federal do Pará (UFPA). Mestranda em Estudos Literários pelo Programa de Pós-graduação em Letras da UFPA. Bolsista Capes. Email: geovanna_marcela@yahoo.com.br.

${ }^{2}$ Doutora em Letras (Letras Vernáculas) pela Universidade Federal do Rio de Janeiro (UFRJ). Professora de Literatura Portuguesa, Instituto de Letras e Comunicação, da Universidade Federal do Pará (UFPA). Professora do Programa de Pós-graduação em Letras da UFPA. Email: izabelaleal@gmail.com. 
comum vermos ensaios e artigos de literatura, tais como o de Rui Torres, "Camões transformado e remontado: o caso de Herberto de Helder" (2006) que se valendo de outro ensaio, Outrora agora: relações dialógicas na poesia portuguesa de invenção (1993) de Maria dos Prazeres Gomes, aproxima a proposta de tradução como criação e releitura da tradição de Haroldo de Campos à tradução e releitura poética desenvolvida por Herberto Helder. Sendo que essa aproximação entre os dois poetas feita por Torres tem como intuito explicar a poesia herbertiana, mais especificamente, a poesia experimental portuguesa, a partir das teorias haroldianas, associando os conceitos de transcriação e plagiotropia ao trabalho poético herbertiano, numa forma de mostrar a desconstrução da tradição empreendida pelo poeta português. Entretanto, ainda não foi realizado um trabalho que estabelecesse uma ponte de convergência entre os dois autores como forma de mostrar que os projetos poéticos de Haroldo de Campos e o de Herberto Helder são semelhantes no que tange à releitura/desconstrução da tradição. Nesse caso, é importante ressaltar que essa convergência, desde o início, implica numa diferença, uma vez que cada poeta ao fazer sua releitura e renovação da tradição, o faz de modo particular e específico que, na maioria das vezes, está ligado ao processo de tradução poética - muito importante para a compreensão do trabalho de criação desenvolvido por ambos - pensada como diálogo entre línguas, culturas, literaturas e autores.

É com vistas a este diálogo que Haroldo de Campos demonstrará um grande interesse pela releitura de clássicos da literatura universal e pela tradução de obras que possuem um alto teor estético. Esta seleção minuciosa visa à transmissão de elementos poéticos presentes no original para a língua materna do tradutor-transcriador; exemplo disso são as traduções/transcriações de poemas orientais, como os haicais e os ideogramas chineses, que, segundo Claudio Daniel, são "uma escrita para olho e para o pensamento, que registra o desenho da coisa e não o seu nome" (DANIEL, 2005, p. 183), buscando resgatar pela tradução o poético, a melodia, a visualidade e a musicalidade da poesia oriental. Já Herberto Helder demonstra um considerável interesse pela tradução de poemas de tribos indígenas sulamericanas, comumente chamadas de línguas primitivas ou ameríndias, sendo um exemplo disso o seu livro de tradução Poemas Ameríndios (1997) em que há traduções de poemas dos caxinauás, dos maias e dos astecas. Além disso, outra convergência que é possível observar entre as obras poéticas de Haroldo de Campos e Herberto Helder está relacionada ao diálogo que ambos mantêm com a obra poética de Luis Vaz de Camões, pensado como um dos alvos privilegiados da releitura crítica e criativa da tradição, ou seja, da visada antropofágica, eixo central da nossa discussão.

O estabelecimento de um diálogo poético entre Haroldo de Campos e Herberto Helder, a partir da discussão antropofágica, não poderá deixar de lado o papel que a tradição representa para os projetos poéticos de ambos, pois a antropofagia, além de ser um processo de devoração violenta do outro, é também o diálogo do passado com o presente, representado pelo poeta e pela tradição. É o que veremos, no caso de Herberto Helder, em poemas como "O Poema"; "Amor em Visita", "Elegia múltipla" e "Teoria Sentada" e em alguns fragmentos de Os Selos (1979) e de Os Selos, Outros, Múltiplos (1990). Com essa observação é possível fazer uma primeira constatação: a antropofagia em Campos e Helder possui um valor ideológico diferente, que reside no fato de que em Campos a antropofagia assume também um caráter político, uma vez que ela será uma ferramenta que proporcionará o diálogo entre o universal e o local, enquanto que em Herberto Helder ela possui uma configuração muito mais pessoal da criação de uma poética própria ou de idioma poético próprio.

A antropofagia como criação poética em Haroldo de Campos está intimamente ligada à discussão do lugar da literatura brasileira no cenário literário universal e na visão da 
antropofagia como sendo a arma da "contraconquista". Nesse sentido, a antropofagia haroldiana é coletiva, uma vez que ela questionará o lugar de uma nação, de um povo dentro do cenário literário universal, e não no lugar do poeta dentro deste cenário, ao contrário da antropofagia herbertiana, que por ser individual é muito mais radical e destruidora, evidenciando que a principal diferença entre as obras poéticas dos dois poetas é a tomada da antropofagia não apenas como trabalho estético, mas também como trabalho político. Se atentarmos bem, notaremos que essa diferença é nitidamente marcada pela nacionalidade dos dois poetas: Haroldo de Campos é brasileiro e Herberto Helder, português. Segundo Haro \ldo de Campos, a antropofagia é essencialmente a instauração de um cenário literário onde as ditas nações periféricas não serão mais vistas como "menores" ou "inferiores", mas, sim, como "iguais" perante as nações ditas "superiores" ou "desenvolvidas".

\section{ANTROPOFAGIA EM HAROLDO DE CAMPOS}

Em "Da razão antropofágica: diálogo e diferença na cultura brasileira" (2010) e "Só a antropofagia nos une" (2002), respectivamente, de Haroldo de Campos e de Maria Cândida Ferreira de Almeida, observamos o caráter político da antropofagia quando, na sua revalorização nas décadas de 60 e 70, esta ideia é usada como instrumento cultural de combate à industrialização e à modernização dos países globais ou de primeiro mundo que viam os países latino-americanos, despossuídos de todo o aparato tecnológico e econômico, como atrasados ou, mais categoricamente, subdesenvolvidos. A discussão que se dá em relação a essa determinação gira em torno do fato de que se tratando das nações latino-americanas, o termo subdesenvolvimento saiu da esfera estritamente econômica e tecnológica para adentrar a esfera cultural e literária. Resumindo, o termo subdesenvolvimento, que se restringia apenas ao meio econômico-tecnológico, estendeu-se às produções culturais, tornando economia e cultura o reflexo uma da outra.

Segundo Octavio Paz em "Invenção, Subdesenvolvimento, Modernidade" (1996) e "A revolta do futuro" (2013), essa junção entre economia e cultura, a partir do termo subdesenvolvimento, ocorre por causa da ambiguidade que o termo comporta, pois ele não possui uma significação exata nem na antropologia e nem na história, sendo somente usado por economistas e sociólogos, acabando por originar generalizações indevidas, tais como: a determinação de que existe apenas um parâmetro de civilização em detrimento da existência de outros e a visão da progressividade retilínea da história, no sentido de que se não há mudanças históricas, não haveria o recomeço do ciclo da história, mas sim o seu fim. Para Paz, é preciso lembrar que não existe uma única civilização e que em nenhuma cultura o desenvolvimento é linear e progressivo, pois a "história desconhece a linha reta" (PAZ, 2013, 32.). Nessa perspectiva, a busca incessante pelo desenvolvimento é uma "desenfreada carreira para chegar mais cedo que os outros ao inferno" (PAZ, 2013, p. 32.). Ao afirmar isso, o autor demonstra sua total descrença no termo subdesenvolvimento, imputado aos países latinoamericanos, pois ele pressupõe uma relação de causa e efeito entre "prosperidade econômica e excelência artística" (PAZ, 1996, p. 135.).

A antropofagia representa uma possibilidade de desconstrução dessa relação de causa e feito ao mostrar que os países latino-americanos, apesar de não possuírem o mesmo poder econômico dos países globalizados, são capazes de produzir/criar uma cultura forte e nova. A devoração do legado cultural estrangeiro é um traço de ruptura, pois o estrangeiro é "transvalorado" e "transubstanciado" de maneira crítica e seletiva na estética latino-americana. É o que diz Haroldo de Campos (2010, p. 234-235):

\footnotetext{
${ }^{1}$ Termo utilizado por José Lezama Lima em A expressão americana (1988) para designar o processo de mestiçagem
} presente na formação cultural latino-americana. 
A “Antropofagia” oswaldiana [...] não envolve uma submissão (uma catequese), mas uma "transculturação"; melhor ainda, uma "transvaloração"; uma visão crítica da história como função negativa (no sentido de Nietzsche), capaz tanto de apropriação como de expropriação, desierarquização, desconstrução.

Para Ferreira de Almeida, a devoração pressupõe uma relação com a alteridade, e o próprio Oswald de Andrade já destacava o papel do "outro" na constituição do "eu", o que acarreta a inclusão do "diferente" dentro do discurso hegemônico "que se propunha desde o século XIX a ser branqueador" (ALMEIDA, 2002, p. 123). O diferente, que antes era visto como "abominável", agora ganha status de produção criativa: o "eu" diferente latinoamericano se apropria do "outro" europeu para se constituir.

É possível ver em Haroldo de Campos toda essa delimitação político-estética, no momento em que ele afirma que a antropofagia nada mais é do que o "nacional em relacionamento dialógico e dialético com o universal" (CAMPOS, 2010, p. 234). Por esse motivo, podemos dizer que a antropofagia, tal como ele a encena, é muito menos radical do que a antropofagia proposta por Herberto Helder, uma vez que num projeto de construção de uma nacionalidade no âmbito da universalidade, não há sentido nenhum a total desconstrução e transformação do outro, do legado cultural estrangeiro, que é componente primordial desse projeto. No caso da América Latina, o "eu", latino-americano, e o "outro", europeu, se unem para formar um novo elemento que terá particularidades totalmente distintas daquelas que o originaram.

A delimitação político-estético da antropofagia na obra poética haroldiana engendra uma discussão da formação da literatura brasileira e latino-americana no cenário literário universal. Para exemplificar isso, tomemos como base o ensaio crítico "Tradição, Transcriação, Transculturação: o ponto de vista do ex-cêntrico" (2013) em que Haroldo de Campos afirma que a literatura brasileira, assim como toda a literatura latino-americana, nasceu sob o signo do barroco. Entretanto, ele afirma que a concepção de nascimento não é aquela que determina a ligação "placentária" e, muito menos, "sanguínea" que ligaria eternamente barroco e literatura brasileira. Se assim fosse, estaríamos insinuando que a literatura brasileira teve sua origem no barroco, coisa que Haroldo de Campos descarta completamente ao enfatizar que a "literatura brasileira não teve origem no sentimento genético, embrionário-evolutivo do texto, pois não teve infância [...]" (CAMPOS, 2013, p. 198). O barroco já chega às Américas trazendo códigos universais rebuscados e evoluídos, fazendo com que a literatura brasileira já nascesse adulta. É por este motivo que Haroldo de Campos, ao tratar da questão do "nacionalismo" literário brasileiro, defende a ideia de que não podemos considerar a nossa literatura como sendo fechada e monadológica.

\footnotetext{
Desde o barroco, ou seja, desde sempre, não nos podemos pensar como identidade fechada e conclusa, mas, sim, como diferença, como abertura, como movimento dialógico da diferença, contra o pano de fundo do universal. Nossa entrada no palco literário é, desde logo, um salto vertiginoso na cena do barroco, ou seja, uma articulação diferencial com um código universal extremamente sofisticado (CAMPOS, 2013, p. 198).
}

Haroldo de Campos conclui que não podemos conceber nossa identidade cultural segundo os parâmetros de unidade e pureza, mas sim como diferença, uma vez que nascemos sob o signo do barroco. A questão do barroco como formação da literatura latino-americana estará presente na seguinte afirmação feita pelo autor em "Minha Relação com a Tradição é Musical” (2010), entrevista concedida em 1983 a Rodrigo Navarres, “[...] o dispositivo barroquizante é algo que tem, para mim, uma importância decisiva no modo latino-americano de apropriar-se criativamente do passado" (CAMPOS, 2010, p. 261-262). É com a tomada do barroco como fundação e como diferença que a consciência nacional latino-americana terá início. Para Haroldo de Campos, "a incorporação da tradição, por um escritor latino- 
americano, se faz [...] pela 'lógica do terceiro excluído', ou seja, pela lógica expropriatória e devorativa do ex-cêntrico, do descentrado" (CAMPOS, 2010, p. 261). Afirmação esta que nos leva à questão do subdesenvolvimento já discutido.

Para compreendemos de maneira mais sucinta a questão da antropofagia como criação poética na obra de Haroldo de Campos é imprescindível que falemos sobre os seus trabalhos como tradutor de poesia, pois é a partir de sua teoria da tradução que iremos entender como a antropofagia pode ser encarada como releitura e inovação da tradição. É por meio da tradução de obras estrangeiras do cânone universal que o ideal antropofágico de apropriação do legado cultural estrangeiro será concretizado. Segundo Inês Oseki-Dépré em "Make it New" (2005), e Lúcia Santaella em "Transcriar, Transluzir, Transluciferar: a teoria da tradução de Haroldo de Campos" (2005), Haroldo associa antropofagia e tradução, partindo do princípio do "make it new" poundiano, que consiste na mistura de arcaísmos e de expressões modernas. Porém, em seu caso, o "make it new" se dará pela mistura do clássico com o coloquial.

Podemos dizer que a antropofagia, em consonância com os trabalhos de tradução e releitura, também opera no limiar entre o clássico, o moderno e o coloquial, já que o passado é relido e atualizado no presente da poesia moderna, ocasionando um diálogo entre tradição e modernidade. Em Finismundo: a última viagem (1990), a encenação do "make it new" poundiano se dará com a poesia contemporânea assumindo o sentido de reescrita, a partir da representação do desejo de Odisseu em ultrapassar o:

\author{
Destino: o desatino o não mapeado \\ Finismundo: alio nde começa a infranqueada \\ fronteira do extracéu. \\ ( CAMPOS, 1990, s/p)
}

Haroldo de Campos (1990), no posfácio do referido livro, afirma que divide o poema em duas partes: uma clássica, regida pela épica, e o outra pela ironia da poesia contemporânea de uma sociedade "abandonada pelos deuses" (CAMPOS, 1990, s/p), cujos ouvidos são incapazes de ouvir o canto das sereias, "o ultrassom incaptado a ouvido humano" (CAMPOS, 1990, s/p). É o estabelecimento de uma nova leitura da tradição que vemos na obra poética de Haroldo de Campos e as traduções, pensadas como releituras, serão também encaradas como recriações poéticas que levam em consideração "a dialética entre os elementos macroestéticos (ou semântico-ideológicos) e os microestéticos (estruturas significantes internas)" (SANTAELLA, 2005, p. 222). Esta colocação de Santaella reafirma o que é dito por OsekiDépré (2005) quanto à recriação poética entendida como uma relevante ferramenta de constituição não somente do poeta, sendo também o "modo mais adequado para formação de uma cultura nacional" (OSEKI-DÉPRÉ, 2005, p. 218). É possível observar a presença do manifesto antropofágico de 1928 nos anos 60-70 e a teoria de tradução/transcriação desenvolvida por Haroldo de Campos como a encenação do diálogo entre passado e presente, culturas, línguas e literaturas. É como diz Santaella (2005, p. 231-232):

A tradução é, portanto, uma "forma de leitura apropriadora e transformadora da tradição [...] Além disso, o empenho na "reinvenção da tradição para propósitos produtivos (não meramente conservativos), no contexto da América Latina, abre-se para uma perspectiva "transumanista" necessariamente antropofágica". 
Estabelecendo uma ponte de convergência entre as práticas tradutórias de Haroldo de Campos e Herberto Helder, podemos dizer que ambas prezam o diálogo, a diferença, o hibridismo, a mestiçagem e a pluralidade das línguas, abandonando a concepção de tradução perfeita, aquela que visa à unidade e universalidade entre as línguas, em favor da diferença como origem, tal como é proposto por Paul Ricoeur em Sobre a Tradução (2011). Ricoeur afirma que a felicidade da tradução é a aceitação da inexistência da chamada tradução perfeita ou tradução absoluta, aquela que só traria ganhos para a língua materna, no sentido de que:

É esse luto da tradução absoluta que faz a felicidade de traduzir. A felicidade do tradutor é um ganho quando ligada à perda do absoluto linguístico, ela aceita a distância entre a adequação e a equivalência, a equivalência sem adequação. Nisso está a felicidade. Admitindo e resumindo a irredutibilidade do par do próprio e do estrangeiro, o tradutor encontra a sua recompensa no reconhecimento do estatuto incontornável da dialogicidade do ato de traduzir como o horizonte razoável do desejo de traduzir (RICOEUR, 2011, p. 29-30).

As práticas tradutórias haroldiana e herbertiana aceitam o luto da tradução absoluta em favor da felicidade de se traduzir a diferença, representando assim, segundo Ricoeur, a hospitalidade linguística, que é a aceitação da língua estrangeira dentro da língua materna como forma de alargamento de estruturas e formas, tanto poéticas quanto estéticas. A consciência dessa hospitalidade entre as línguas permite a compreensão do sentido não como algo imanente à obra, mas sim como algo que precisa ser construído e criado. A construção do sentido se dá por meio de metáforas e semelhanças entre o que está expresso na língua de partida e o que está expresso na língua de chegada. É no contato entre línguas distintas que a língua materna do tradutor irá se alargar para receber a língua estrangeira e assim propor uma nova leitura, uma nova criação poética. Além disso, é possível constatar que as práticas dos dois poetas possuem as mesmas particularidades presentes na tradução de poesia, no sentido de que ambos valorizam a leitura crítica e reflexiva das obras traduzidas, da mesma maneira que veem a tradução como uma partitura musical, onde somente o som, o ritmo e o tom das palavras serão levados em consideração, pois é deles que o sentido emergirá. Ao fazerem isso, Haroldo de Campos e Herberto Helder deixam "o abrigo confortável das equivalências" (RICOEUR, 2011, p. 69) e partem rumo ao mundo da linguagem e dos signos, onde somente o tradutor-transcriador pode adentrar. Com isso, vemos que as práticas tradutórias tanto de Haroldo de Campos quanto de Herberto Helder são exemplos de aproximação entre a língua materna e a língua estrangeira na expressão de uma tradução poética que propõe a ruptura das ideologias dominantes.

O resgate das línguas primitivas realizado por Herberto Helder, a partir da tradução dos poemas indígenas, significa um ato de revolta contra a língua materna, uma vez que dá a elas o lugar que outrora - na época das Grandes Navegações e do Descobrimento - lhes foi arrancado e renegado, o do poético. Já em Haroldo de Campos não há revolta com a língua materna e, muito menos, com a língua estrangeira, em vez disso, há a aceitação do nosso passado como colônia e a busca por uma identidade nacional no panorama globalizado como sendo a transgressão dos padrões dominantes. A antropofagia, quando surge no Brasil em 1928 e na revalorização nos anos 60-70, não propõe a rejeição do passado, mas sim a aceitação dele, valorizando o que já foi criado, escrito e canonizado, pois é a partir da tradição que o novo será produzido. A antropofagia é o diálogo do passado com o presente, do nacional com o estrangeiro, do clássico com o moderno. E foi esse caráter dialógico que Haroldo de Campos valorizou em sua obra poética e crítica, encenando a diferença como diálogo entre línguas e culturas, e não como separação e distância. 


\section{Antropofagia em Herberto Helder}

Em Herberto Helder, a antropofagia pressupõe uma relação com a alteridade que envolve autor, texto e leitor, num movimento que leva ao desvendamento do lado selvagem do homem. Sangue, garras, unhas e boca terão voz numa violência poética que transformará completamente aquilo que conhecemos. A devoração do outro é a base da criação poética, onde o essencial será a produção de um idioma poético próprio. $\mathrm{O}$ artigo "A "antropófaga festa: metáfora para uma ideia de poesia em Herberto Helder" (2009) de Ana Lúcia Guerreiro analisa os doze poemas do livro Antropofagias (1971), pensando o caráter individual e subjetivo da antropofagia herbertiana como um processo crítico de si mesmo. É uma antropofagia que constitui um sujeito, e não uma nação, pondo em diálogo o poeta, seus antecessores e seus leitores, no que representaria uma partilha espiritual - estritamente ligada à poesia e à linguagem - entre aquele que escreve e aquele que lê. Além disso, a antropofagia herbertiana é marcada pela relação de amor e ódio entre poeta e tradição, caracterizada comumente pela figura da mãe, onde ambos estão em constante embate. Embate este que causa a morte do poeta e o silenciar de seu canto. O passado é metaforizado como sendo a musa, o canto, a mãe, que levam o poeta para o desconhecido e a solidão. É também o lugar dos mortos que chamam, do mundo das sombras, o poeta:

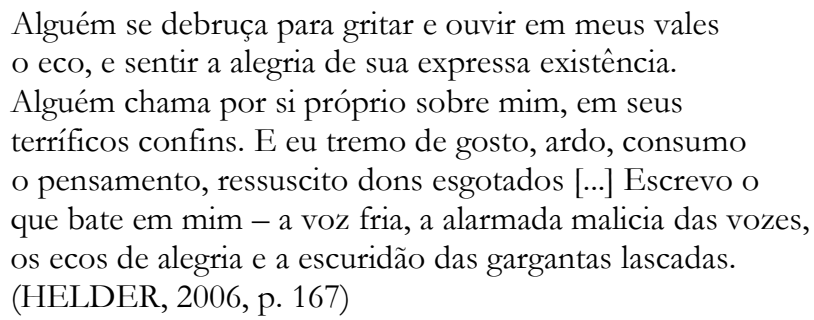

Neste trecho do poema "Teoria Sentada" que faz parte do livro Lugar (2006) há a representação do momento em que o poeta é chamado pelo passado, "Alguém" - que pode ser interpretado como sendo a encenação da figura dos mortos -, para que cante o que já foi esquecido e silenciado, recebendo em mãos a responsabilidade de ressuscitar "dons esgotados". O esquecido e o silenciado na tradição podem ser vislumbrados nas línguas primitivas, concebidas como fonte originária da linguagem humana. Por isso, é possível dizer que Herberto Helder, quando traduz poemas de povos primitivos ou faz releituras de clássicos da tradição, está em busca dessa língua de origem, ou melhor, dessa voz universal.

$$
\begin{aligned}
& \text { Alguém se procura dentro de meu ardor escuro, e reconhece as noites } \\
& \text { espantosas do seu próprio silêncio. E eu falo e vejo as mudanças e o } \\
& \text { imóvel sentido do meu amor, e vejo minha boca aberta contra minha } \\
& \text { própria boca num amargo fundo de vozes universais (HELDER, 2006, p. 57.) }
\end{aligned}
$$

As vozes universais, destacadas no trecho acima, são a representação das tão conhecidas vozes comunicantes, que interligam o poeta, a tradição e a poesia. Tal compreensão obtida com a leitura do poema herbertiano nos faz ver que a atitude do poeta perante a tradição dá a ver uma descontinuidade poética, num processo em que há a rejeição da tradição por meio da destruição de textos, poema "2." de Exemplos (2006), e a aceitação das musas, do canto e dos mortos - figuras representativas da tradição - que chamam por ele:

Eu abaixava-me e tomava como nos braços

essa criança ignota.

E porões enchiam-se de água, eu seria em breve

um afogado. Tudo me inspirava

nessa noite abrupta, entre o começo e o fim 


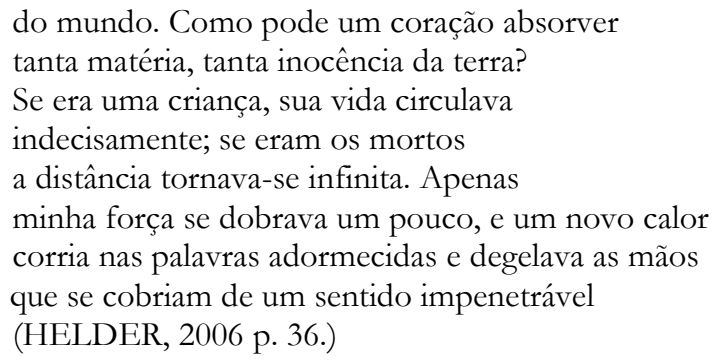

A aceitação da inspiração, que vem como um raio, uma luz, uma revelação é o que proporcionará a renovação da tradição. Será ela quem dará calor àquilo que é frio e adormecido, pois "Nenhuma vida tanto se gastou/ que não seja visitada, nenhum deus/ é tão grande que se não perca na substância da sombra [...]” (HELDER, 2006, p. 28.) A musa e o canto, signos da criação poética, são um exemplo da inspiração que vem do passado. Em poemas como "Amor em Visita", a musa é a mulher amada e desejada pelo poeta e a fonte de onde tudo será criado, mãe da poesia. É através dela que tudo será cantado e criado.

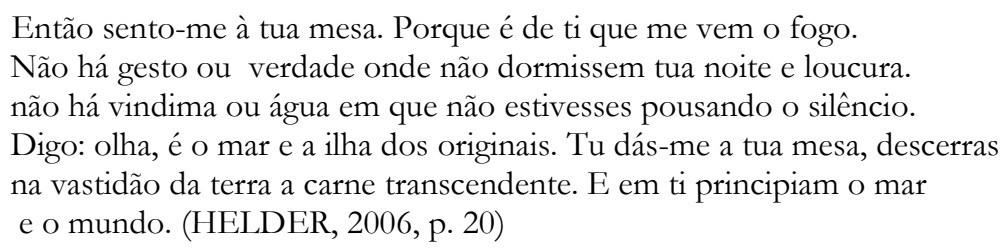

Já a destruição dos textos é uma forma de Herberto Helder nos dizer que não quer ser visto como um poeta seguidor de uma determinada influência, ao mesmo tempo em que ele sabe que faz parte de uma. Em "Herberto Helder e os Dispositivos de Diálogo Cultural" (2013), Izabela Leal pensa os procedimentos poéticos de Herberto Helder, como a citação direta e indireta de textos alheios e os seus trabalhos de tradução como:

Uma proposta que apenas problematiza a própria ideia estanque de um passado morto e de uma tradição fixa e congelada, mas também pressupõe uma visão calcada na ideia de descontinuidade, de reconfiguração permanente, de interrupção no curso da história (LEAL, 2013, p. 203).

No caso de Herberto Helder, segundo Leal, é preciso se pensar numa "não-tradição", levando-se em consideração o surgimento de um modelo de literatura mundial marcado pela fluidez, no sentido de que este modelo comportaria toda a descontinuidade e a desconstrução da poesia herbertiana. É Herberto Helder, seguindo o seu padrão descontínuo, quem escolhe suas influências, seus precursores, num processo que caracteriza um provável projeto de poética sincrônica, mas que Leal (2013, p. 205) prefere chamar de "afinidades eletivas".

Nesse ponto diríamos que Herberto Helder e Haroldo de Campos fazem uma verdadeira seleção crítica daquilo que será lido e relido em seus poemas, pois a releitura de outros textos, canônicos ou não, só ocorrerá quando estes apresentam um trabalho poético esteticamente inovador. Um exemplo disso, na obra poética de Haroldo de Campos, é o caso de poetas como Sousândrade, Dante Alighieri, Camões, Gregório de Mattos, Mallarmé, dentre outros. Em Herberto Helder, a antologia Edoi Lelia Doura (1985) - que será composta, principalmente, por autores e poetas considerados "menores" dentro do panorama literário português - será o exemplo da releitura crítica e criativa do presente e não do passado como ocorre em Haroldo de Campos. A presença de autores "menores" na antologia composta por Helder é a demonstração de que a releitura não é algo descompromissado e, muito menos, 
acrítico. $\mathrm{Na}$ antropofagia herbertiana esse processo é o vislumbre de uma criação poética crítica e inventiva que busca o poético nas vozes "menores", mas admiravelmente comunicantes, da moderna poesia portuguesa.

Além desses aspectos, vemos no livro Os Selos, mais especificamente no fragmento "A poesia pode também ser isso" (HELDER, 2006, p. 457), que a antropofagia herbertiana possui um laço forte com o canibalismo, tendo em vista que canibalismo e antropofagia são práticas diferentes, tal como é discutido no texto "Antropofagia e os limites da representação", presente no ensaio Além do visivel: o olhar da literatura (2007) de Karl Erik Schøllhammer, que destaca o caráter ambíguo da visão do homem europeu sobre a antropofagia: ora encarada como algo irrepresentável e incompreensível, ora como um ato simbólico, cuja apreciação e admiração são inevitáveis. O autor destaca que desde o início a antropofagia foi usada como instrumento de crítica dos valores do homem europeu, colonizador, e que por isso houve a necessidade de se distinguir o índio "canibal" do índio "antropófago", sendo "o primeiro [...] o homem que barbaramente come seus semelhantes para se nutrir e o segundo [..] aquele que come ou ingere carne humana em ritos simbólicos que se destinam a dignificar a vítima e os valores comunitários" (SCHOLLHAMMER, 2007, p. 201).

No fragmento "A poesia pode também ser isso", a afirmação "Devoro a minha língua" caracteriza não somente um canibalismo, mas também uma autofagia: o poeta devora a si mesmo. A poesia aparece como um ritual, ou melhor, um batismo em que o poeta é purificado e abençoado com o dom da linguagem poética. O que dará a ele o poder de falar de todas as coisas de forma inesperada e surpreendente.

\footnotetext{
Porque tudo é canto de louvor na vida inspirada, tudo porque acaba na mesa: garfo e faca às faíscas e a carne no prato. Devoro a minha língua: cintila ainda. Lirismo antropofágico, visão, oh sucessivo. A poesia é um baptismo atónito, sim uma palavra surpreendida para cada coisa: nobreza, um supremo etc. das vozes (HELDER, 2006, p. 458.)
}

Em "Devoro a minha língua" está contido este processo simultâneo de antropofagiaautofagia-canibal, pois a devoração da língua representa a devoração não apenas de si, mas também da linguagem, pois a língua a que o poeta remete não é simplesmente o órgão humano, é a língua materna constantemente representada pela figura da mãe ou, como está no poema, da madre. É o que podemos ver em outro texto de Leal, "No reino das mães: notas sobre o poético em Herberto Helder" (2008), que afirma que o embate entre poeta e língua materna/mãe para criação de um idioma próprio é necessário à formação do poeta que não se daria sem uma "certa dose de violência [...]" (LEAL, 2008, p. 127). Na busca pelo seu idioma poético - aquilo que o distingue dos demais - o poeta se insurge contra a língua materna, sua mãe que o acolheu tão afetuosamente em seu seio. Essa insurreição, por parte do poeta, é oriunda do desejo de amadurecimento que ele nutre em relação à poesia, ao seu fazer poético, tornando-se perante a língua materna o "Filho intratável". Filho este que devora sua própria mãe, enquanto ela morre:

\footnotetext{
Devoram-me enquanto morro até aos núcleos do ouro na sombra. Um dia tocaram-me nos centros doces e abrasados vi que os espelhos se moviam entre os polos, os rostos enfeixavam-me no meu rosto arco a arco numa única matéria. E a dor? À noite bebo água quieta, durmo, as chamas desatam-se. E é com isso que sonho, imagem às faíscas, o sitio selvagem mas suavíssimo, absoluto.a imagem inabitável que eu habito, um dom.[...] Porque são filhos vivo da minha água vibrante, do meu fôlego, mão a mão dos raios de quando adormeço.
} 


\section{(HELDER, 2006, p. 472.)}

Neste fragmento de Os selos, outros, últimos (2006) a mãe, apesar de estar sendo devorada pelos filhos, não demonstra nenhum ressentimento contra eles, ao contrário, demonstra serenidade e resignação. É como se ela soubesse que essa devoração fosse necessária para que eles amadureçam, pois somente assim o seu dom, que está escondido nas profundezas das águas, será descoberto. É possível perceber na poesia herbertina que a figura da mãe está intrinsecamente ligada à figura da água, sendo que uma possível explicação para isso residiria no fato de que mãe e água são metáforas para vida e energia. Com isso, concluímos que a antropofagia herbertiana visa a uma criação poética de sentido estritamente pessoal, onde as metáforas para a devoração da tradição são múltiplas, porém todas apontam para a necessidade de manter o que há de mais essencial na poesia: a inspiração, a linguagem e a criação.

\section{Considerações finais}

A convergência antropofágica existente entre Haroldo de Campos e Herberto Helder é a compreensão da antropofagia como instrumento de seleção crítica para a criação de uma poética que renega os padrões estabelecidos pela tradição em prol da valorização de obras e autores esquecidos por ela, caracterizando, desta maneira, um diálogo entre passado e presente, onde a crítica terá papel fundamental, pois a (re)visitação do passado pelos poetas terá como objetivo a busca de "novas" formas poéticas, estéticas e artísticas possíveis de serem atualizadas nas poéticas do presente. Haroldo de Campos dirá que a característica da arte do nosso tempo - isso em meados dos anos 70, mas que pode muito bem ser aplicado aos dias atuais - é que ela "é cada vez mais uma arte 'metalinguística', ou seja, uma arte crítica [onde] o poeta faz contínuas operações críticas" (CAMPOS, 1977, p. 74), o que nos faz ver que o trabalho poético empreendido por ele e por Herberto Helder é um constante processo de crítica e releitura da tradição. Trata-se de um minucioso trabalho de transformação da história por meio da linguagem, que em Haroldo é marcado pela crítica e pela reflexão e em Herberto Helder pelo desregramento e pela violência.

Para finalizar, com a leitura do ensaio "Tradição da Ruptura" (2013), de Octavio Paz, podemos pensar as obras poéticas de Haroldo de Campos e Herberto Helder como exemplos da chamada tradição da ruptura, ou melhor, da tradição moderna, por serem obras que propõem o rompimento da poesia com os padrões universais da tradição, já que elas valorizam o passado para poder romper com o presente institucionalizado e ideológico da sociedade moderna, para, em seguida, propor uma nova tradição que será baseada na diferença e na heterogeneidade. $\mathrm{Na}$ antropofagia, a releitura crítica e criativa do passado não ocorrerá a partir de qualquer obra. Somente as obras com alto teor criativo, estético e poético serão relidas pelo fato de que elas servirão como fonte de reflexão para o presente. Por isso, podemos dizer que as escolhas de Haroldo de Campos e de Herberto Helder são conscientes. Segundo Paz (2013, p. 21), essa consciência é a principal característica da tradição da ruptura:

Aquele que sabe que pertence a uma tradição já sabe, implicitamente, ser diferente dela, e esse saber o leva, mais cedo ou mais tarde a questioná-la e, às vezes, a negá-la. A crítica da tradição se inicia como consciência de pertencer a uma tradição.

A consciência de fazerem parte de uma tradição e, consequentemente, da mudança que operam sobre ela faz com que Haroldo de Campos e Herberto Helder sejam considerados poetas originais e talentosos. Para Campos e Helder, a mudança e a novidade são produzidas 
por um gesto antropofágico encenado como manifestação de uma tradição não estanque e convocadora, que de uma hora para outra, como uma revelação, chama o poeta apto para renová-la e ressignificá-la, pois é do passado que emerge o novo.

\section{REFERÊNCIAS}

CAMPOS, Haroldo de. "Da razão antropofágica: diálogo e diferença na cultura brasileira". In:_Metalinguagem e Outras Metas: ensaios de teoria e crítica. 4. ed. São Paulo: Perspectiva, 2010, p. 231-255.

"Minha relação com a tradição é musical". In: Metalinguagem e Outras Metas: ensaios de teoria e crítica. 4. ed. São Paulo: Perspectiva, 2010, p. 257-267.

Finismundo: a última viagem. Tipografia do Fundo de Ouro Preto, 1990.

"Transcriação, Tradução, Transculturação: o ponto de vista do ex-cêntrico". In: TÁPIA, Marcelo; NÓBREGA, Thelma Médici (Orgs.). Haroldo de Campos Transcriação. São Paulo: Perspectiva, 2013, p. 197-205.

"Aspectos da poesia de vanguarda no Brasil e em Portugal: Entrevista de Haroldo de Campos a E.M de Melo e Castro". In: Ruptura dos gêneros na literatura latinoamericana. São Paulo: Perspectiva, 1977, p. 51-75.

DANIEL, Claúdio. "Um oriente além do oriente: releituras de Haroldo de Campos". In: TENÓRIO DA MOTA, Leda (Org.). Céu acima: para um "tombeau" de Haroldo de Campos. São Paulo: Perspectiva; Fapesp, 2005, p. 183-191.

FERREIRA DE ALMEIDA, Maria Candida. "Só a antropofagia nos une". In: MATO, Daniel (Coord.). Estudios y otras prácticas intelectuales latinoamericanas em cultura y poder. Caracas: Clacso (Consejo Latinoamericano de Ciencias Sociales), p. 122-132, 2002. Disponível em: <http://www.globalcult.org.ve/pdf/Ferreira.pdf> Acesso em: 05/01/2014.

GUERREIRO, Ana Lúcia. “A 'Antropófaga festa', metáfora para uma ideia de poesia em Herberto Helder". Diacrítica, Ciências da Literatura, n. 23, v.3, p. 9-22, 2009. Disponível em: <http://ceh.ilch.uminho.pt/publicacoes/Diacr\%C3\%ADtica_23-3.pdf > Acesso em: $10 / 04 / 2014$.

HELDER, Herberto. "A Colher na Boca". In: Ou poema contínuo. São Paulo: Girafa Editora, 2006, p. 7-100. "Lugar". In: Ou poema contínuo. São Paulo: Girafa Editora, 2006, p. 123180. . "Os selos". In: Ou poema contínuo. São Paulo: Girafa Editora, 2006, p. 437465.

"Os selos, outros, últimos". In: Ou poema contínuo. São Paulo: Girafa Editora, 2006, p. 467-480. p. 301-314. "Exemplos". In: Ou poema contínuo. São Paulo: Girafa Editora, 2006, 
1997.

Poemas Ameríndios: poemas mudados para o português. Lisboa: Assírio \& Alvim,

(Org). Edoi Lelia Dora: antologia das vozes comunicantes da poesia moderna portuguesa. Lisboa: Assírio \& Alvim, 1985.

LEAL, Izabela. "Herberto Helder e os dispositivos de diálogo cultural". In: BUENO, Luís; SALES, Germana; AUGUSTI, Valéria (Orgs.). A tradição literária brasileira: entre a periferia e o centro. Chapecó: Argos, 2013, p. 203-219.

"No reino das mães: notas sobre a poética de Herberto Helder". In: Cadernos de

Letras da UFF: Dossiê Literatura, Língua e Identidade, n. 34, p. 127-138, 2008. Disponível em: < http://www.uff.br/cadernosdeletrasuff/34/artigo8.pdf>. Acesso em: 08/01/2014.

LIMA, José Lezama. A expressão americana. Tradução Irlemar Chiampi. São Paulo: Brasiliense, 1988.

OSEKI-DÉPRÉ, Inês. “Make it new”. In: MOTA, Leda Tenório da. (Org.). Céu acima: para um “tombeu”de Haroldo de Campos. São Paulo: Perspectiva: Fapesp, 2005, p. 213-220.

PAZ, Octavio. "Tradição da Ruptura". In:

Os filhos do barro: do romantismo à vanguarda. Tradução Ari Roitman e Paulina Wacht. São Paulo: Cosac Naify, 2013.

."Invenção, Desenvolvimento, Modernidade". In: Signos em Rotação. São

Paulo: Perspectiva, 1996, p. 133-137.

RICOEUR, Paul. Sobre a Tradução. Tradução de Patrícia Lavelle. Belo Horizonte: Editora UFMG, 2011.

SANTAELLA, Lucia. "Transcriar, Tranasluzir, Transluciferar: a teoria da tradução de Haroldo de Campos". In: TENÓRIO DA MOTA, Leda (Org.). Céu acima: para um "tombeau” de Haroldo de Campos. São Paulo: Perspectiva; Fapesp, 2005, p. 221-232.

SCHØLLHAMMER, Karl Erik. "A Antropofagia e os limites da representação". In:

Além do visível: o olhar da literatura. Rio de Janeiro: 7 Letras, 2007, p. 195-207.

TORRES, Rui. "Camões Transformado e Re-montado: o caso de Herberto Helder". Revista

Callema, n. 1, p. 58-64, nov. 2006.

Recebido em 21/04/2014

Aprovado em 23/08/2014 